\title{
Supervision and Quality Assurance Strategies in Education: Implication for Educational Policy Making \\ B.J. Ojo (PhD)
}

\section{Abstract:}

This paper examines the need for quality assurance and quality control strategies in improving the effectiveness of educational provision and teacher performance in schools. Governments all over the word in an attempt to educate and develop their citizens spend huge amount of money on teachers and schools but in most cases especially in the developing counties the case has been that of continuous falling in the standard and quality of their education. In fact, in some, it is near collapse. This paper found that there is the need for introduction of strategies that would lead to re engineering of schools and introduction of effective supervisory management of the educational sector. The Paper recommends that an important division of the ministry of education must be empowered and strengthened as a strong driving force to justify the lunge investment on education.

\section{Introduction}

Education plays a major role in the life of any nation (Ajayi 1997). Education is not only regarded as a very important instrument of socialization and reform, but as a means of laying foundation for a strong and virile nation; it is regarded as the instrument for development and integration, hence concerted efforts are always made to ensure that the system is on course through effective monitoring and supervision. From holistic view- point, Education is a 
consensus, organized and systematic process a society uses to transmit its values and ethos across time and space.

For any education system to succeed, the operators or implementers play a very vital and prominent role. No matter how laudable and lofty the objectives of any system or policy might be, if not well implemented, they will be difficult to attain. The success or failure of an educational programme depends on the way and manner school heads and teachers implement it in the classroom. It is one thing to design a beautiful program, get all the needed facilities ready (both human and material) it is another to provide a conducive learning atmosphere and get the program effectively implemented. The need for an effective supervision of instruction can not be over emphasized if the needed quality is to be guaranteed and the education of any nation is to be productive. It is often very common in recent times to hear of the allegations of falling standard of education. Aina (1994) asserts that, education is in crisis and in dire need of rethinking and remaking. It is an all engulfing, all encompassing crisis affecting all levels of education and all its significant elements namely: governance, finance, access, quality, relevance and direction. In fact it is a crisis that threatens the entire process of social and cultural reproduction of entire national systems. Fafunwa, in Fagbamiye (2004) correctly observed that the standard of education is not what the issue is. "What is actually falling is our ability to meet the set standards". The implication of this is that standards had already being established for education, but the practitioners or implementers have often failed in ensuring that such standards are attained and maintained. In addition, Ajayi (1997) points out that, teachers have been accused of abandoning their classrooms and not being as dedicated and committed to duty as they used to be in the past. School heads too have not been spared in these criticisms. They too have been accused of not being alive to 
their leadership and supervisory responsibilities. (Obaro 1971) Ajayi (1983) confirmed that many school heads are in effective in their curriculum and instructional responsibilities.

Seyoun Tefera (1996) commenting on the state of education in Ethiopia stated that administration of education was characterized by a bloated bureaucracy that stifled local initiative and efficiency. Quoting Aklilu's study, Tefera stated that the image that elementary school teachers had of the ministry of Education was that: "The ministry is some times pictured as a remote island peopled with in competent and corrupt clercks and administrators, who's sole pre- occupationbesides coffee drinking and gossip - is the devising of ways and means to oppress others. Teachers further alleged that the degree of oppression and suppression increases with the distance of the school from Addis Ababa and the provincial capitals".

Negase (2007) in a public lecture at Bahir Dar University concluded education in Ethiopia as being on the brinks of collapse. Adewumi and Ajayi (2001) opined that in response to critics of quality of education and as a measure of improvement on the glaring downward tread on the standard of education, school supervision has become a veritable instrument for checking teacher and student performances. They maintained that school inspection was included by the missionary bodies that introduced western education with a view to ensuring that their school produced primarily morally sound Nigerians while they did not ignore standard, efficiency and professionalism.

Fafunwa, Adesina and Taiwo in Fagbamiye(2004) were of the opinion that the availability of complete and committed teachers will enhance the efforts being made by all concerned to solve the prevailing problem that bedevil the educational system, since it is a foregone conclusion that no education system can rise above the quality of its teachers . 
It is there fore important to note that bearing all other factors, effective supervision of instructional staff is a major modality of integrating productive work in to the school system (Ajayi, 1986). Obilade (1987) was of the opinion that the importance of supervision in our schools cannot be over emphasized especially at this period when there is a growing concern about the falling standards of education and low quality of education in our schools.

In this paper there fore, attempts would be made at explaining what quality assurance in education and ways by which supervision of instruction can be made effective within the school system.

\section{Education and Quality Assurance:}

Babalola (2004) stated that: quality of education refers to the worth of education (with reference to its input, the teaching- learning process and the output/ out come). It is measured against set standards and could either be seen as below, exactly or as above a given standard. Babalola went further to explain that, the quality could be poor, just as expected, excellent or exceptional. When it is exactly as it ought to be, we say it is an expected quality. Above the standard, we say it is either excellent or exceptional. Quality of input refers to the worth of teachers, trainees, textbooks, technology of delivery, and tasks or curriculum. Quality of the process deals with the worth of teaching learning process that involves lesson plans, delivery methods, classroom organization and control, student-teacher inter actions, pupils' participation, assessment and evaluation, marking etc, Quality of outcome and output involves the academic achievement and attainment, value added through education, results of internal and external examinations, etc. Quality of environment involves the work of all environmental factors and sanitation etc. Since education is seen and regarded as service to the society and as such a predominant force in our society. The services it renders 
must be good and qualitative. Good service doesn't just happen by chance; it must be planned and managed, from the design to the delivery, from maintaining efficient operations to ensuring that the quality is both high and insistent quality assurance therefore deals with the proactive means of ensuring quality inputs, quality through puts, quality outcome, quality academic achievements of pupils and the environment before things get our of hands (Babalola 2004). It aims at preventing quality problems and ensuring that only conforming products reach the customers. This is in contrast to quality control which aims at remediating an existing or recouping problem within the system.

Quality according to Gatewood et.al (1995) is the degree to which a good service meets the standards and requirements of the market place. It means excellence, value and reliability. In educational sense, It means conformity with specification, it is meeting and / or exceeding parents and pupils /students expectations; and it is satisfying and delighting parents and pupils /students. The focus is on nothing less than optimum quality as perceived by parents and pupils or students. [Jaja in Ojo (2003)].

Quality Assurance in Education therefore involves in a broad sense the prevention of quality problems through planned and systematic activities. This prevention strategy concentrates all the attention on the front end of the processthe inputs-and changes emphasis to making sure that the inputs are capable of meeting the requirements of the process. Little wonder then, the International standard organization (ISO) puts it that the concept of quality should be seen as the totality of features and characteristics of a product or service that bear on its ability to satisfy stated or implied needs. Quality Assurance therefore provides a set of rules which if followed, can provide for more effective ways of operating a viable educational enterprise; it will permit eradication of the 
demanding nuisance or idiot view of customers, which is pervasive in many other organizations.

\section{Steps to Quality Assurance:}

To ensure a qualitative education in our school system, Babalola (2004) posits that the following steps can be taken. These include:

Monitoring: This has to do with keeping a watchful eye on the input, process, output and the environment of an education system to ensure that things keep going the right direction and according to the set standards. For example, monitoring of pupils' progress from one class to another.

Evaluation: This involves assessment, appraisal, valuation and estimation of the worth of education inputs, process and outcome for the purposes making judgment and corrective criticism.

Supervision: This deals with overseeing those who are responsible for one thing or the other (teaching, learning, resource utilization, management, etc) in the process of educating a pupil.

Inspection: This is more penetrating and piercing than supervision. It is job - focused and scientific in approach. It involves close examination, check, scrutiny and assessment of available facilities and assessment of available resources in an institution with a view to establishing how far a particular institution has met prescribed standards.

\section{Supervision and Qualitative Education}

According to Good cited in Ajayi (1997) supervision is:

All efforts of designated school officials towards providing leadership to teachers and other educational workers in the improvement of instruction. It involves the stimulation of professional growth and development of teachers, a selection and revision of educational objectives, materials of instruction and methods of teaching, and the evaluation of instruction. 
Joseph Cobb (1988) defines supervision to mean "... working through others and with others in order to achieve school goals." Ben Harris in Cobb (1988) says "it is what school personnel do with adults and things for the purpose of maintaining or changing the operation of the school in order to directly influence the attainment of major instructional goals." It should be made clear from the outset that; supervision is concerned with improving the setting for learning, and should have a democratic base, a philosophy that respects individual differences, and assumes teachers are capable of growth, initiative, self-reliance, and responsibility. It is creative, not perceptive, and proceeds in an orderly cooperatively planned and executed sense of activities. (Burton and Brueckner in Cobb 1988)) Kimball Wiles in Adesina (1988) sees a supervisor as one who expedites, stimulates, supports, and encourages the teachers to try new things. He helps people accept each other, and grow through their interaction, by supporting, assisting, and sharing rather than directing. Harmes, Wife and Dickney cited in Ajayi (1985) are of the view that instructional supervision in basically concerned with any thing that furthers the development and improvement of the teaching- learning situation in the school system. In other words it is concerned with ways and means of making teachers work effectively and also making pupils learn so that the school system can achieve goals for which it is set-up. It is thus one of the many instruments for quality assurance and quality control of the educational system. Its main thrust is helping people to change their concept of self, way of behaving, attitudes to and/or within the school communities fostering a relationship and creating the climate for the teachers to meet targets. Supervisory climate according to Adewumi and Ajayi (2001) is the interaction between supervisor and teacher in schools. It 
relates to the behavior the supervisor exhibited in the course of his duties.

Naturally, the supervisor is primarily a resource person, a teacher of teachers who poses a sound education, well informed about methodology of classroom management, inventive, zealous and acutely sensitive to people's cultural values, patient, a good listener and very friendly. Because they (Supervisors) work with human concerns in a school, and are dedicated to the belief that the school should serve the people, rather than the people serving the school their ultimate purpose is human growth, which they promote by supplying continuity and constant re-adaptation in the educational programme. They seek improved methods of teaching and learning, and coordinate and integrate all educational efforts and materials. Supervision is an essential part of any organizational set up, the ultimate purpose of which is the promotion and development of favorable setting for teaching and learning as well as the stimulation, overseeing and appraisal of activities leading to an achievement of instructional goals at a specified quality level.

Secondly, supervision is essential in order to monitor the execution of the curriculum making sure that the curriculum is carried out at a zero level defect. Through supervision, inexperienced teachers are assisted to grow, even the experienced ones though qualified, professionally competent and can be trusted still need to be supervised in order to continue to maintain the high standards. As a result of supervision, teachers learn to isolate and analyze their problems, develop confidence in their ability to solve problems, the ultimate goal of which is to improve instruction.

\section{Conclusion and Recommendation}

Since the enduring urge to bring to bear regularly expert and seasoned influence on teaching is not an idle design, every responsible government must view supervision of 
its education with all seriousness it deserves. Standards should be set, policies should be established as to the standards of attainment of the aims which education of the nation sets out to achieve.

Aims and objectives of education being provided in the schools must be clearly stated; supervisors with clear evidence of proven academic records and good methodology appointed with the sole aim of achieving these aims. Studies have emphatically proved and confirmed the views of several educational commentators and writers that proper and effective supervision can inject new life in to the school systems and improve teacher performance. The supervisory section of the education ministries should be reorganized, equipped with adequate materials and fund to operate effectively. In essence, the qualities of human and material resources injected in to education in any nation have a strong relationship with schools academic performance. Fuller in Adedeji (2001) opined that the quality of school management can be conceptualized with in a linear framework, such that a principal acquires a variable level of skills and credentials necessary in becoming a strong, leader and supervisor.

The fact remains that, the responsibilities assigned to school leaders are greater now than in the past, it is obvious, that the quality of school leaders must be improved upon to affect or have positive impact or academic performance of teachers and students. The school principals must be reorientated consciously to create a super- vision of where they want their institutions to be; they should equally promote excellence in education and establish an educational environment and culture in which this can be achieved. Under these circumstances therefore, only competent professionals should occupy supervisory positions for the purpose of achieving good academic performance for the school. 
Responsive governments should not only ensure that capable hands are recruited and utilized but should equally ensure that resources are not lacking but should be made available to these supervisors and are closely monitored to see that things are done in a proper way so that the nation can be built.

\section{References}

Ajayi, K.(1997): "Instructional Supervision and Practices in Primary schools": Effective Management of Primary Education; Ajayi and Sokan (1997) Ed., Ibadan, Adeose T.C.S. Bodija.

Adewumi and Ajayi (2001): "The Relationship Between Supervisory Climate and Teacher- Student Performance in Secondary schools in Oyo state, Nigeria" in African Journal of Educational Management, Vol.9 No 1.

Adedeji, O.A (2001): "Managing school Resources for Better Learning Outcome in Osun State Secondary School African Journal of Educational Management, vol.9 no 1.

Aina, A. (1995): "Quality and Relevance: African Universities In the 21st century." Dakar; Association of African Universities.

Adesina, S \& Fagbamiye E.O (1988): Educational Administration. Lbadan: University Press Limited.

Ajayi,A.O(1986): "Qualitative and Quantitative Inspection Visits As a means to a Better School Output." in Dada, A (Ed) Ibadan, Mass Failure in Public Examinations.

Babalola, J.B (2004): Management of primary and secondary Education in Nigeria. NAEP Publication, Ibadan.

Cobb J. (1988): "The Principal as Supervisor". Educational Administration. Ibadan University Press Limited. 
Fafunwa, A. B cited in Fagbamiye E.O (2004): Management of Primary Secondary Education in Nigeria. Ibadan; NAEP Publications.

Fagbamiye, E.O (2004): Providing Cost - Effective Education For Nigerians in the 21st Century. Management of Primary And Secondary Education in Nigeria, Ibadan; NAEP Publications.

Gatewood, (1995): Management: Comprehension Analysis and Application. London, LRWLN Austen Press.

Rabert G. M (1990): Service Operations Management. Boston, ALLyn and Bacon.

Seyoum Tefera (1996): Attempts at Educational Reform in Ethiopia: A top- down or a Bottom-up Reform? Ethiopian Journal of education vol XVI № I .pp1-33.

Lucio and McNeil (1979): Supervision in Thought and Action. New York, Mc-GrawHill, Inc.

Obilade, S.O (1987): Changing value system as a factor in the Poor Performance of Students on Mass Failure in Public examination. Seminar Paper, University of Ibadan.

Ojo, B. J. (2003): Commandant Managerial Capacity and Workers Productivity in Nigeria Police Force Schools. Unpublished PhD Thesis University of Ibadan. 